\title{
Institutional Mechanisms and Civic Forum in Coastal Village Governance in Indonesia
}

\author{
Nurlinah \\ Department of Government, Faculty of Social and Political Sciences, \\ Universitas Hasanuddin \\ Haryanto \\ Department of Political Science, Faculty of Social and Political Sciences, \\ Universitas Hasanuddin
}

cross $^{r e f}$ http://dx.doi.org/10.5755/j01.ppaa.19.3.27832

\begin{abstract}
Studies on village governance in Indonesia, especially in the maritime areas since the passage of new village law regulations, have not been so comprehensive in analyzing coastal village governance. This article aims to describe and analyze village governance in enhancing public accountability. The study was conducted by taking the case of coastal villages in South Sulawesi. We have carried out some analyses by identifying issues with institutional mechanisms and civic forums. The results show generally minimal community involvement in the governance of coastal villages and low capacity of the village governments. The practice of coastal village governance shows a tendency to place more emphasis on administrative accountability than public accountability. These two main problems focus on three factors: institutional relations in village governance, the way social organizations work in local communities, and cultures. These three factors differ in practice from one another in how they determine the level of accountability in each village. However, in principle, their main characteristic is a weak presence of good governance in the community and village government in the Indonesian coastal area.
\end{abstract}

Keywords: governance; coastal village; village law; civic; Indonesia. Indonezija.

Raktažodžiai: valdymas, pakrančiu urbanizuotos teritorijos, vietos teisé, pilietinis,

\section{Introduction}

In Indonesia, village governance is problematic. The problem is with the forms of improving community welfare, developing village infrastructure, and public services. In many villages in Indonesia, the evaluation results are low (Hartoyo, Haryanto, and Fahmi 2018; Nurlinah, Haryanto, and Musdah 2018). Theoretically, the low impact of development is caused by problematic governance (Eko 2014; Nurlinah, Haryanto, and Sunardi 2020), and elite capture (Warren and Visser 2016), including resource management conflicts (Yamazaki et al. 2018; Steenbergen 2016).

Some recent village analyses have also concluded that the problems lie with governance (Jakimow 2014; Antlöv, Wetterberg, and Dharmawan 2016; Vel, Berenschot, and Minarchek 2016; Salim et al. 2017; Sutiyo and Maharjan 2017). Nor is village law considered to provide an adequate basis for managing proper financial management, especially in preventing corruption (Novrizal and Podger 2014, 29). There has been considerable research on villages in Indonesia since decentralization and democratization. Previous research was dominated by sociological and anthropological studies (Koentjaraningrat 1967; Skinner 1959). In the last decade, economic and environmental studies took a dominant role. Meanwhile, the study of government, especially village governance, has been relatively small, even following passage of the Village Law in 2014 which 
encouraged greater research on villages. It is where this paper tries to better analyze how governance has been affected by the new regulations.

The following studies provide an overview of problems regarding villages in general and specifically regarding governance in Indonesia. The main idea from this body of work is that the changes in regulation of villages have to do with the paradigm of rural development. The paradigm has been changing from the development being driven by the state and community towards villagedriven development. Specifically, the new paradigm entails that the village is seen not only as providing administrative services or only as an extension of the government above it, but the village can also provide basic services, develop local economic assets, develop infrastructure and utilise natural resources and the environment in a sustainable manner (Eko, 2014). We conclude that the research of Sutoro Eko (2014) and his team is early and an advanced, strong, independent, democratic and prosperous village is still a vision based on the future Village Law. For this reason, the research we are conducting now aims to envision and evaluate practices that occur after the Village Law has been implemented. Importantly, our research will close the gap left by Sutoro Eko's research, especially in terms of village governance in coastal areas.

Tanya Jakimow (2014) conducted another study entitled "Decentralized Governance as Sites for Self-Formation: A Comparison of Practices of Welfare Distribution in Telangana, India, and Central Lombok, Indonesia." Associated with villages in Indonesia, Tanya Jakimow aimed to examine the effects of decentralization and social changes on institutional dynamics as a result of the new government regime. Her research explores the effects of decentralized government on the involvement of individuals, rural communities, and their relations with the state. For rural communities, governance in the presence of decentralization is a matter of welfare policy (Jakimow $2014,175)$. Thus it is the welfare issue that encourages discursive practices in rural communities, such as attending meetings, attending general elections, taking part in supervision, being members of various committees, and so on. Jakimow's research indicates that there is no ideal governance perspective. Both government and rural communities imagine the State only as a nurse, a "nanny state," by distributing various needs to the community. Surely this is a primary reference that the presence of the Village Law might be able to change the paradigm of the government and village communities, as described by Ms. Jakimow. Meanwhile, other research analyzing villages also summarizes issues of governance (Antlöv, Wetterberg, and Dharmawan 2016; Vel, Berenschot, and Minarchek 2016; Salim et al. 2017; Sutiyo and Maharjan 2017), including the problem of corruption (Novrizal and Podger 2014; Susan and Budirahayu 2018). However, these studies have not looked further at the issue of public accountability.

Therefore, this article aims to describe and analyze village governance in the enhancement of public accountability in coastal areas of Indonesia. We will trace more deeply the implementation of governance in coastal villages that have not previously been closely studied. In turn, this research looks to whether villages at the level of public accountability are able to ultimately implement good village governance.

\section{Methods}

This qualitative study aimed at understanding the social knowledge of the community. Intensive fieldwork was conducted in the first half of 2018. The data were collected from in-depth interviews with key informants. Data from archives of local regulations that have been issued by the village government were also analysed. For determining the location of the study, three selective steps were taken. First, we interviewed the service heads and Community and Village Empowerment staff in Takalar and Pangkep districts. The initial reference for choosing these villages was that they thought they were best in their governance. Second, recommendations from "village assistants" who are very knowledgeable about the village governance were taken. We interviewed two to three village facilitators in each district, who then appointed one of the best villages in the village governance. Third, we inventorised data from the 2018 Developing Village Index in the two districts. 
We conducted intensive research in two districts in the province of South Sulawesi. The villages selected were villages in the coastal area, along with the coastline of the Sulawesi Sea. The first field research was conducted in Takalar district, an area that is directly adjacent to the provincial capital, Makassar city. In this area, the chosen village is one of the coastal villages that are in the developing category, namely the Tamasaju village. This village was chosen because it became the primary reference for village governance from several village facilitators in Takalar.

Moreover, Tamasaju is a fishermen's village in Takalar. The profession of fishermen in this village reaches almost 200 or approximately $47 \%$ of all professions. This number does not include fishermen's families. This means that Tamasaju is a village which can be seen as representative of coastal villages and can generate comprehensive findings in terms of coastal villages.

Meanwhile, in Pangkep district, the research was conducted in the villages of Pitusunggu and Pitue. Both villages cultivate fishery in the form of fish and shrimp ponds. Pitusunggu and Pitue are the best villages in Pangkep district according to the local government. Both were prepared to become independent regions and took part in village competitions representing the Pangkep district several times. In 2018, Pitue village was chosen to represent Pangkep district in the Provincial Village competition.

\section{Results and Discussion}

\section{Reorganising Power in Indonesian Village}

After the reforms of 1998, a wave of decentralisation and regional autonomy has triggered a change in political maps in Indonesia. This change is in line with the increasingly dynamic legal basis for government administration, following the development of the political situation in the country. During the New Order, the administration of the government relied heavily on a centralised system with the central government as the primary control of government administration. The reforms that took place in 1998 forced the Indonesian government to reorganise centralisation, which in practice rested on one axis of power ignoring local participation. Decentralisation and regional autonomy were presented as antitheses from the centralisation of government that was deemed ineffective in institutionalising regional aspirations (Tambunan, 2000). It did not stop there and in early 2014 a wave of decentralisation and autonomy rolled back. This time, villages were the target. In short, legal products that legalise decentralisation and regional autonomy as new faces of the administration of government in Indonesia are the entry points for the reorganization of power relations that take place on a local scale, including villages.

After the collapse of the New Order in 1998, a legal product of Law No. 22/1999 concerning Regional Government was issued to adjust the process of governance in the spirit of reform. The spirit of this policy is the emphasis on the decentralised government system and regional autonomy. This spirit is in tune with the socio-political context that took place at that time. Indonesia has just emerged from the New Order authoritarian system because it requires a more dynamic government system. The aim is to open a more comprehensive administration office. More specifically, for the governance of villages, this regulation still places decentralisation and autonomy in the village as false. Villages are no more than parts of government units that are charged with tasks from the provincial and/or district governments through the sub-district. In this case, the spirit of the principle of "coadministration" which took place in that era also involved the village government. However, as a result of Law No. 22/1999, the village has got more open space. The village already has its autonomy, even though it is still at a minimal level. One of the most striking issues of the authority of the village government is the legal recognition of local (adat) communities in the village. This authority was not recognised during the New Order regime.

The next wave of decentralisation and autonomy was carried out through Law No. 6/2014 (the Village Law). This regulation brings the spirit of broader autonomy to the village government. Decentralisation and village autonomy are the main pillars that are the front-runners for the implementation of governance at the village level. This regulation also serves as the entry point for 
changing the political map at the village level. Through this regulation, the village government is one part of the political intensity that is sufficiently calculated at the local scale. Some scholars refer to this regulation as a new chapter of the village government to escape the grip of government domination, which has taken root since the New Order regime (Antlöv et al., 2016).

The Village Law has facilitated a more circumscribed political space for officials and villagers. Among them, the village is given the authority to regulate its household affairs, such as development planning and village finance. Thus, the village government is more independent and the dependence on authority decreases. The independence of the village government can be seen in the aspect of the administration of the village government, which consists of the village apparatus, namely the village head and the village consultative parliament (BPD). These executive and legislative two institutions are charged with tasks and functions. Village heads are government executives at the village level, while the legislature is mandated to work on budget planning, village regulation in the direction of development that will take place in the village. This scheme, as a whole, has a significant impact on changes in power relations that occur in the village. Within this scheme, the village government is not confronted with authority over it, but with village officials themselves between the village head and the BPD, while the relationship between village government and subdistricts and districts is limited to governmental relations. Sub-district and district governments have minimal space to intervene with village officials, although in reality some co-optation patterns are still found at the village level. The village is still used as an instrument to perpetuate power, especially for the incumbent regent, who returns to fight in the local election (Haryanto, 2017).

At present, the village has the opportunity to manage the development, governance and social life of the village autonomously through the village fund. By utilising the village fund, the village is expected to play a more active role in driving the development of rural communities. However, village funds also have a substantial political impact on the position of the village head. With village funds, the village government becomes a party that has a political bargaining power before the sub-district government or even the district. Village funds have reduced the dependence on village governments from budget allocations sourced from the APBD. This situation gradually decreased the dependence of the village head on the regional government. As a result, politically, the village head dared to be at odds with the sub-district government and district government when there were policies which he considered not to be in the interest of the village.

\section{Between Accountability and Superiority of Village Head}

Another problem that accompanies the Village Law in Indonesia is accountability that village heads must deal with because every year the budget of village funds increases (see Table 1). From data reported by the Ministry of Finance of the Republic of Indonesia, up to 2020, the village funds budget amounted to 72 trillion rupiahs (approximately 5 million USD), far higher than the previous year, 2015, when village funds were only in the range of 1 million USD with the average village receiving 20,000 USD. In 2020, each village received 68,614 USD in village funds from the total village funds budgeted at 5.1 million USD.

Table 1. Village fund 2015-2020

\begin{tabular}{|c|r|r|}
\hline YEAR & VILLAGE FUND (USD) & AVERAGE FOR EACH VILLAGE (USD) \\
\hline 2015 & $1,483,300,000$ & 20,000 \\
\hline 2016 & $3,355,864,286$ & 44,857 \\
\hline 2017 & $4,157,142,857$ & 57,143 \\
\hline 2018 & $4,285,714,286$ & 57,171 \\
\hline 2019 & $5,000,000,000$ & 66,709 \\
\hline 2020 & $5,142,857,143$ & 68,614 \\
\hline
\end{tabular}


On the one hand, village funds that are so large minimise the dependence of rural communities on the government. The village government can use village funds at any time; the amount exceeds 1 billion every year. The Village Law only mandates village heads to build relationships with the Regional development banks (BPD) as the legislative body in the village regarding the use of the village budget, so that the village head no longer has to be afraid of being held hostage by the deposition of development funds that were previously heavily controlled by the district government. As explained earlier, if the Village Law provides a wide range of autonomy to the village, including the planning and use of the budget, it is an obstacle to the mechanism of accountability and transparency in the use of village funds.

For example, in Takalar, the yearly allocation of village funds is intended to help fishermen's communities reach tens of millions rupiahs, whose allocation comes from village funds. Normatively there is nothing wrong with this form of assistance, but in practice, the definition of allocations for assistance still causes polemics, such as assistance to who and what it is intended. When this happens, the one who has the authority to provide the assistance is the village head. For example, the village head of Tamasaju admitted that dozens of boats and hundreds of nets had been held to support fishermen's activities in Takalar. The procurement budget is sourced from village funds, but once i tis confirmed in the field, not all poor people receive assistance. Political closeness with the village head is one reason that can influence the distribution of aid sourced from village funds.

“Every year, village funds carry a huge impact, including support for fishermen's activities. For example, this year the allocation of village funds was used to help small fishermen to procure fishing gear and boats for, where the source of funds used came from village funds."

\section{Village Head of Tamasaju, interview 29 July, 2018}

The same thing happened in the village of Pitusunggu, Pangkep. The political size of the village head had left serious questions about the accountability mechanism for the use of village funds. In the context of coastal villages in Pangkep, the superior authority of the village head also sidelined the role and existence of the BPD, a budgeting agency and village government supervisors. On his initiative, the village head often assists fish farmers for business capital assistance. This assistance was provided without prior coordination with the BPD. Although it was found in the field, the assistance obtained by fishermen farmers was sufficient enough to help the economy of the local community. With the help of funds from the village, the community can increase the production quota. However, in the context of accountability, the provision of assistance that is based on closeness with the village head without coordination with the BPD is very vulnerable to fraud by the village head. Who should get help and what is the amount to be given will be important questions. In Pangkep, the assistance and the amount of assistance provided to farmers depend on the village head. For example, one community received the assistance of five million rupiahs for the development of a crab business, while another community running the same business only received the assistance of three million rupiahs. So far, detailed mechanisms and procedural issues regarding the use of village funds in the field are still very loose; the village head often controls so many cases of distribution of village fund assistance.

"There has never been assistance from the village. Two years ago there was an order to collect identity cards for village officials, which was said would be intended for data collection assistance for fishermen. However, until now, there has not been any assistance from the village. To date, none of the people in this village has ever received assistance. Unless I do not know, but I do not know anywhere else. Maybe the assistance referred to by the village pack is distributed elsewhere, not in this hamlet." 
The common thread of the two cases above is the aspect of village fund accountability. BPD as the legislative institution in the village is mandated by the Village Law as the check and balance of the village head. Procedurally, the village head must be responsible to the village community through the BPD. This form of accountability is internal; from the village head to the village community as a manifestation of accountability for the use of village funds. However, the limited quality of human resources contributes significantly to the weak supervision process carried out by BPD. The position of the BPD in the village is sometimes a post for community leaders who are considered parents in the village, even though their education is not seen as important. In the case of the two villages in Pangkep and Takalar, the highest level of education of BPD members is only high school education, while in the village government apparatus, the average level of education is undergraduate. Village heads in both Pangkep and Takalar are scholars, including village staff, most of whom also have a bachelor's degree. Differences in the level of education are also a serious problem that contributes to strengthening the superiority of village heads: educational background tends to be the instrument of social capital used by village officials. Therefore, when dealing with BPD, the village head has a much higher trust than the BPD. As a result, political processes, including issues related to the village budget, will be very easily controlled and won by the village head.

The external responsibility of the village head also includes external accountability which must be carried out by sending village activity files to the district government through sub-district governments in each region. External accountability also has little impact on the position of the village head. Specifically, the form of external accountability is only reporting on the action plan, while the authority that continues the activity is returned to the village government. The position of the subdistrict head (camat) and the regency government is limited to providing administrative support, which shows that the planning and accountability provided by the village are in line with the applicable procedures and mechanisms. Districts have no room to replace, abort programs or cancel activities. The most significant contribution that can be made by the subdistrict government is to advise on activities, which again are returned to the village government to be discussed with the BPD and other villagers.

Furthermore, the accountability mechanism carried out by the village head does not arrive at detailed reporting. Although the form of village budget reporting with digital systems has been used, it remains difficult to confirm the posts of budget allocation for activities. The information is enough to reach the total budget, including external accountability models that use information boards in the village office. The village head of Tamasaju admitted that the installation of billboards that included activities and the amount of budget used for a year was considered a form of accountability to the general public. The head reported the same thing of Pitusunggu in Pangkep. However, both forms of external answer support that use different media (digital and information boards) are still minimal for villagers. There is no room to clarify the model, target and purpose of the activity in question further. The impression demonstrated is limited to the socialization of village activities rather than any substantive information that would open the space for public accountability.

\section{Isolated Participation}

The participation of rural communities is a fundamental issue amid the strong wave of decentralization and village autonomy. The participation of rural communities is an option for supervising village funds from the stagnation of the role and communication of the BPD by the village apparatus (Marpaung 2018). That is exactly what happened twice, in Pangkep and Takalar. Second, the village law has recognized the existence of rural communities, giving them formal access to get involved in the processes that take place in the village (Pauwelussen 2016; Chomariyah, Hudi, and Ariyanto 2016). Third, ultimately, the participation of the village community is essential to minimize the domination of the village head, whose political position has grown stronger after the ratification of the Village Law. 
The BPD's poor relations with the village apparatus affected the form of very isolated community participation. The BPD as a legislative institution in the village does not only play a role in supervising and controlling the running of the government in the village, but is also required to be able to absorb the aspirations of the village community for better village development. The interaction of the BPD and village heads as two very strategic institutions in the village greatly determines the direction of village development. In some cases, ongoing functional interactions between the BPD and village apparatus have been successful enough to boost community participation (Marpaung, 2018), especially in the form of reciprocal interaction: the BPD communicates with village officials as representatives of the community by voicing the aspirations of the community and communicates with the community as an extension of the village head in order to socialise the village work program. These reciprocal relationships are equally beneficial both for village officials and for rural communities. Unfortunately, this relationship did not take place in Pangkep and Takalar. The BPD's interaction with the village head only took place when there were BPD meetings with village officials. Therefore, the interactions were rigid and tended to be formal. Apart from that, the BPD failed to absorb communication in non-formal areas, while the problem of community life was more acute in the non-formal arena. The story of the difficulty of fishing is more often communicated from one house to another. This state of contradiction was found throughout the research in Takalar and Pangkep. Complaints from the community and the failure to understand the problem of village development is one of the cases which shows the breakdown of participation in non-formal spaces.

In addition, the lack of participation of coastal communities due to the failure of the village apparatus empowered traditional fishing communities. The Village Law has given recognition to the existence of traditional communities in the village. Unfortunately, in Pangkep and Takalar, traditional fishermen communities have not been integrated within village participation schemes. In Takalar, it has indeed opened a space for community involvement with a forum or musyawarah (Musrembang) pattern at the village level by inviting fishermen's families. In Pangkep, participation was boosted by conducting Musrembang starting at the hamlet level before going to the village Musrembang. The ongoing process rarely involves local communities and not only established fishermen groups whose welfare levels are much better. This means that the direction and development plans in the village do not touch the root of fishermen's problems, such as poverty and dependency patterns (Haryanto, 2017) and community involvement and activities have been excluded from the village agenda.

In places such as Kalimantan, traditional communities in trans-local forms are used as a local knowledge base to involve fishing communities on the development agenda (Pauwelussen, 2016). This pattern has not yet been seen in Pangkep and Takalar; both villages have not been actively engaging traditional fishing communities as a local knowledge base to empower and encourage fisherman participation. Traditional communities are usually formed by the proximity and similarity of professions. For example, in Takalar, there are papalele (retainer) and mustard; in Pangkep, there are petambak and fishermen of shrimp and crabs. Fishers are therefore heterogeneous professionally and different fishing communities can be formed. Thus, the participation space produced will also be very different depending on the extent to which the development agenda in the village can absorb the community in each region, both in Pangkep and Takalar.

In Takalar and Pangkep, community participation is still a trigger for the stagnation of the process that takes place in the village, such as the lack of community involvement in planning, supervision and participation in village work programs. This has an impact on the crippling wheel of government at the village level: the strong dominance of the village head and the weak accountability of village funds, as has been explained in the discussion above.

The Village Law guarantees and provides a space for the involvement of village community participation in the administration of the village. Specifically, one exacmple is the presence of Bumdes (Village-Owned Enterprises) as one of the mouthpieces of the village community. Bumdes as a village-owned business entity is expected to reduce poverty in the village. This can be seen from the commitment of the government, which continues to provide funds for the management of Bumdes. Until 2017, the allocation reached up to 100 million rupiahs budgeted from village funds 
for Bumdes activities, including Pangkep and Takalar regions. Due to the lack of community participation the amount of funds that have been disbursed has not maximally impacted the welfare of the community. One indication of this is the contribution of Bumdes that has not been able to trigger the productivity of fishers in both Pangkep and Takalar. The disconnection of fishermen's participation channel is a strong reason and Bumdes, which is supposed to improve the economic conditions of the community, is precisely the opposite of the reality on the ground.

In Takalar, there are still many people who do not know about Bumdes. Once Bumdes activities are confirmed, the community understands Bumdes as a cooperative model which is driven by middlemen. This is because, in Takalar, dozens of cooperatives driven by middlemen have attracted the attention of fishers. Many fishermen families take loans from private-owned cooperatives, with a return of $5 \%$ to $10 \%$ per month in interest. The community views Bumdes as other cooperatives and only note the difference among managers, i.e. whether Bumdes is managed with the permission of the village apparatus.

In Pangkep, the community is familiar with the term Bumdes. Importantly, even though in Pangkep Bumdes activities have contributed to village income to a limited extent, they have encouraged the economy of the community. However, this has not confirmed the form of public participation in general, especially for activities in Bumdes. It was found that the manager of Bumdes in the village of Pitusunggu, Pangkep, had a close relationship with the village head, i.e. the chairman of Bumdes is the nephew of the village head. The access gained through the involvement in Bumdes activities will undoubtedly be different among people who do not have family closeness.

\section{Conclusion}

1. The practice of coastal village governance shows a tendency to place more emphasis on administrative accountability and to override public accountability. The village government prioritizes accountability reports to local governments and the central government rather than to the community. We have carried out some analyses by identifying issues with institutional mechanisms and civic forums. These two main problems focus on three factors: institutional relations in village governance, the way social organizations work in local communities, and cultures.

2. The three factors influence institutional mechanisms and civic forums in villages. These three factors differ from one another in how they determine the level of accountability in each village. However, a weak presence of good governance in Indonesian coastal communities and village governments is their main characteristic. If the government and village communities can optimize these three factors, it will determine the level of governance of coastal villages.

3. This article contributes to understanding how villagers' participation on the one hand and accountability on the other hand do not sustain governance. In the end, the villages in the coastal area are not much different from the problems of governance with other villages in Indonesia. Policy makers should pay attention to two main issues, i.e., institutional mechanisms and civic forum. Both can be a way to increase participation and accountability in village governance in Indonesia in the future.

\section{References}

1. Antlöv, H. (2003). Village Government and Rural Development in Indonesia: The New Democratic Framework. Bulletin of Indonesian Economic Studies, 39(2), 193-214. https://doi.org/10.1080/00074910302013

2. Antlöv, H., Wetterberg, A., \& Dharmawan, L. (2016). Village Governance, Community Life, and the 2014 Village Law in Indonesia. Bulletin of Indonesian Economic Studies, 52(2), 161183. https://doi.org/10.1080/00074918.2015.1129047

3. Chomariyah, Hudi, N., \& Ariyanto, B. (2016). Participation Principle on the 2014 Village Law in Coastal Village. International Journal of Business, Economics and Law, 10(4), 33-40.

4. Eko, S. (2014). Desa Membangun Indonesia. Yogyakarta: Indipt Press. 
5. Hartoyo, Haryanto, S., \& Fahmi, T. (2018). Towards a New Village Development Paradigm in Lampung Province, Indonesia. Journal of Legal, Ethical and Regulatory Issues, 21(3), 117.

6. Haryanto. (2017). Adaptation and Continuities in Clientelism in a Fishing Community in Takalar, South Sulawesi. Contemporary Southeast Asia, 39(3), 511-531. https://doi.org/10.1355/cs39-3f

7. Jakimow, T. (2014). Decentralised Governance as Sites for Self-Formation: A Comparison of Practices of Welfare Distribution in Telangana, India, and Central Lombok, Indonesia. International Journal of Asian Studies, 11(2), 161-185. https://doi.org/10.1017/s1479591414000151

8. Koentjaraningrat. (1967). Villages in Indonesia. New York: Cornell University Press. https://doi.org/10.2307/2798929

9. Marpaung, B. O. (2018). Communication as a Way in the Development of Fishing Village in Belawan Medan Indonesia. Asian Journal of Quality of Life, 3(11), 39-46. https://doi.org/10.21834/ajqol.v3i11.120

10. Novrizal, M., \& Podger, O. (2014). Corruption Prevention in Village Finance Governance. In International Conference on Eradicating Corruption: an Inter-Disciplinary Perspective (pp. 137). Padang: Universitas Andalas.

11. Nurlinah, Haryanto, and Erwin Musdah. 2018. "The Problem of Public Accountability in Village Governance in Rural Enrekang, Indonesia." Mimbar: Jurnal Sosial Dan Pembangunan 34 (2): 332-40. https://doi.org/10.29313/mimbar.v34i2.3578.

12. Nurlinah, Haryanto, and Sunardi. 2020. "New Development, Old Migration, and Governance at Two Villages in Jeneponto, Indonesia." World Development Perspectives, 19 (September): 1-10. https://doi.org/10.1016/j.wdp.2020.100223.

13. Pauwelussen, A. (2016). Community as Network: Exploring a Relational Approach to Social Resilience in Coastal Indonesia. Maritime Studies, 15(1), 1-19. https://doi.org/10.1186/s40152-016-0041-5

14. Salim, A., Bulan, W. R., Untung, B., Laksono, I., \& Brock, K. (2017). Indonesia's Village Law: Enabler or Constraint for More Accountable Governance? Brighton. Retrieved from https://pattiro.or.id/en/2017/11/02/indonesias-village-law-enabler-or-constraint-for-moreaccountable-governance/

15. Skinner, W. (1959). Local, Ethnic, and National Loyalties in Village Indonesia: A Symposium. New Haven: Yale University Press.

16. Steenbergen, D. J. (2016). Strategic Customary Village Leadership in the Context of Marine Conservation and Development in Southeast Maluku, Indonesia. Human Ecology, 44(3), 311327. https://doi.org/10.1007/s10745-016-9829-6

17. Susan, N., \& Budirahayu, T. (2018). Village Government Capacity in the Implementation of Village Law No. 6 of 2015 in Indonesia. In B. McLellan (Ed.), Sustainable Future for Human Security (pp. 17-27). Singapore: Springer Singapore. https://doi.org/10.1007/978-981-105433-4_2

18. Sutiyo, \& Maharjan, K. L. (2017). Decentralization and Rural Development in Indonesia. African Administrative Studies. Singapore: Springer Nature Singapore.

19. Tambunan, M. (2000). Indonesia's New Challenges and Opportunities: Blueprint for Reform After the Economic Crisis. East Asia, 18(2), 50-74. https://doi.org/10.1007/s12140-0000027-0

20. Vel, J., Berenschot, W., \& Minarchek, R. D. (2016). Report of the Workshop "New Law, New Villages? Changing Rural Indonesia." Leiden. Retrieved from http://www.kitlv.nl/workshopnew-law-new-villages-changing-rural-indonesia/

21. Warren, C., \& Visser, L. (2016). The Local Turn: An Introductory Essay Revisiting Leadership, Elite Capture and Good Governance in Indonesian Conservation and 
Development Programs. Human Ecology, 44(3), 277-286. https://doi.org/10.1007/s10745016-9831-z

22. Yamazaki, S., Resosudarmo, B. P., Girsang, W., \& Hoshino, E. (2018). Intra-village and Intervillage Resource Use Conflict in Indonesia: The case of the Kei Islands. Ocean and Coastal Management, 155(1), 50-59. https://doi.org/10.1016/j.ocecoaman.2018.01.022.

Nurlinah, Haryanto

\section{Instituciniai svertai ir piliečių forumas Indonezijos pakrančių gyvenvietėse}

\section{Anotacija}

Vietos savivaldos klausimai Indonezijoje, ypač pakrančių teritorijose, ypač po naujujų vietos savivaldos įstatymo prièmimo, nėa išsamiai išnagrinèti. Šiuo straipsniu siekiama apibūdinti ir išanalizuoti vietos savivaldos teikiamų viešujų paslaugų plètros galimybes, ekonominị, socialinị kapitalą ir efektyvumą didinant viešają atskaitomybę. Tyrimas buvo atliktas atsižvelgiant į pakrantès kaimus Pietų Sulavesyje. Šiame straipsnyje pristatome tyrimo metu gautus rezultatus - identifikuotą institucinių mechanizmų ir piliečių forumų organizavimo principus. Rezultatai rodo, kad pakrančių teritorijose savivalda dažnai apsiriboja tik minimaliai ịtraukiant bendruomenę ị sprendimų prièmimą. Pakrančių savivaldos praktika tendencingai teikia prioritetą administracinę atskaitomybę ir ignoruoja visuomenès atskaitomybès. Šios dvi pagrindinès problemos fokusuojasi ị tris veiksnius: institucinius santykius vietos savivaldoje, tipini socialinių organizacijų darbą vietos bendruomenèse ir vietos kultūrą. Šie trys veiksniai praktikoje skiriasi kiekvienoje iš gyvenviečių taip suformuodami skirtingus atskaitomybès lygius. Tačiau iš esmès tai yra pagrindinė Indonezijos pakrančių gyvenviečių silpnybė vietos savivaldoje.

Nurlinah - Department of Government, Faculty of Social and Political Sciences, Universitas Hasanuddin

E-mail: nurlinah@unhas.ac.id

Haryanto - Department of Political Science, Faculty of Social and Political Sciences, Universitas Hasanuddin.

E-mail: $\underline{\text { harymusi@unhas.ac.id }}$

Nurlinah - Hasanuddin universiteto Socialinių ir politikos mokslų fakulteto Vadybos katedra El. paštas: nurlinah@unhas.ac.id

Haryanto - Hasanuddin universiteto Socialinių ir politikos mokslų fakulteto Politikos mokslų katedra El. paštas: $\underline{\text { harymusi@unhas.ac.id }}$ 